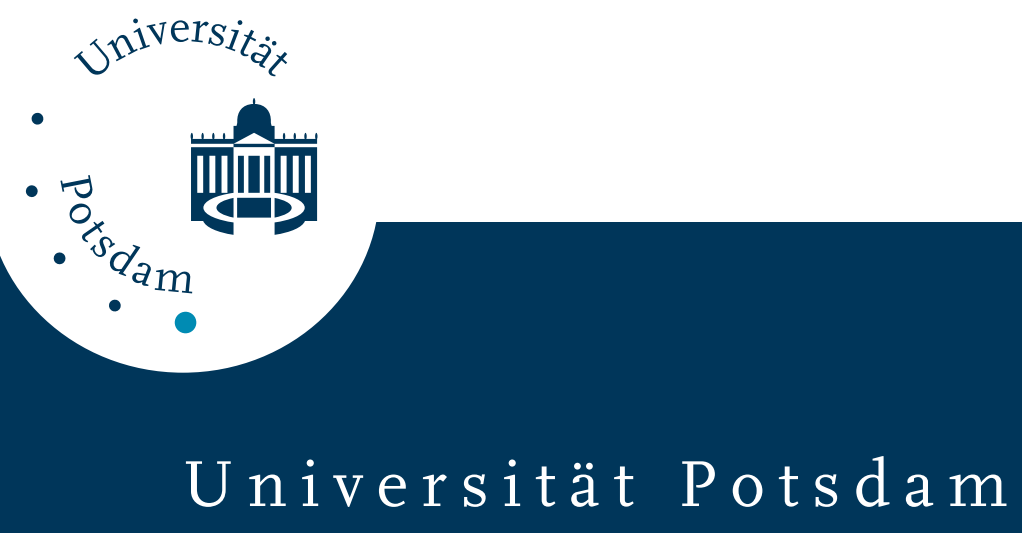

Wolfgang Blenau, Julie A. Mustard, Ingrid S. Hamilton, Vernon K. Ward, Paul R. Ebert, Alison R. Mercer

\title{
Analysis of two D1-like dopamine receptors from the honey bee Apis mellifera reveals agonist-independent activity
}

first published in:

Brain research : Molecular brain research 113 (2003), 1-2, S. 67 - 77, DOI 10.1016/S0169-328X(03)00091-3

Postprint published at the Institutional Repository of the Potsdam University:

In: Postprints der Universität Potsdam

Mathematisch-Naturwissenschaftliche Reihe ; 109

http://opus.kobv.de/ubp/volltexte/2010/4437/

http://nbn-resolving.de/urn:nbn:de:kobv:517-opus-44378

Postprints der Universität Potsdam

Mathematisch-Naturwissenschaftliche Reihe ; 109 

Research report

\title{
Aalysis of two D1-like dopamine receptors from the honey bee Apis mellifera reveals agonist-independent activity
}

\author{
Julie A. Mustard ${ }^{\mathrm{a}, 1}$, Wolfgang Blenau ${ }^{\mathrm{a}, 2}$, Ingrid S. Hamilton ${ }^{\mathrm{a}}$, Vernon K. Ward ${ }^{\mathrm{b}}$, \\ Paul R. Ebert ${ }^{\mathrm{c}}$, Alison R. Mercer ${ }^{\mathrm{a}, *}$ \\ ${ }^{a}$ Department of Zoology, P.O. Box 56, University of Otago, Dunedin, New Zealand \\ ${ }^{\mathrm{b}}$ Department of Microbiology, P.O. Box 56, University of Otago, Dunedin, New Zealand \\ ${ }^{\mathrm{c}}$ Department of Biochemistry, University of Queensland, St. Lucia, QLD 4072, Australia
}

Accepted 3 March 2003

\begin{abstract}
Dopamine is found in many invertebrate organisms, including insects, however, the mechanisms through which this amine operates remain unclear. We have expressed two dopamine receptors cloned from honey bee (AmDOP1 and AmDOP2) in insect cells (Spodoptera frugiperda), and compared their pharmacology directly using production of cAMP as a functional assay. In each assay, AmDOP1 receptors required lower concentrations of dopamine and 6,7-ADTN for maximal activation than AmDOP2 receptors. Conversely, butaclamol and $\operatorname{cis}(Z)$-flupentixo were more potent at blocking the cAMP response mediated through $A m \mathrm{DOP} 2$ than $A m \mathrm{DOP} 1$ receptors. Expression of $A m D O P 1$, but not $A m D O P 2$, receptors significantl increased levels of cAMP even in the absence of ligand. This constitutive activity was blocked by $\operatorname{cis}(Z)$-flupentixol This work provides the firs evidence of a constitutively activated dopamine receptor in invertebrates and suggests that although $A m D O P 1$ and $A m D O P 2$ share much less homology than their vertebrate counterparts, they display a number of functional parallels with the mammalian D1-like dopamine receptors.
\end{abstract}

(C) 2003 Elsevier Science B.V. All rights reserved.

Theme: Neurotransmitters, modulators, transporters, and receptors

Topic: Catecholamine receptors

Keywords: G protein-coupled receptor; Biogenic amine; Invertebrate; cAMP; Baculovirus

\section{Introduction}

Dopamine has been detected in many insect species, but its functions, and the mechanisms through which it operates in the insect brain, remain largely unresolved. In the honey bee, Apis mellifera, dopamine has been implicated in olfactory learning and memory [25,27-29], modulation of motor output [26] and adult development and behaviour $[6,39,46,49]$. To help establish the role of dopamine in these processes, it is important to characterize the receptor

\footnotetext{
*Corresponding author. Tel.: +64-3-479-7961; fax: +64-3-479-7584.

E-mail address: alison.mercer@stonebow.otago.ac.nz (A.R. Mercer). ${ }^{1}$ Present address: Department of Entomology, 1735 Neil Avenue, Ohio State University, Columbus, $\mathrm{OH} 43210$, USA.

${ }^{2}$ Present address: Institute for Biochemistry and Biology, P.O. Box 601553, University of Potsdam, D-14415 Potsdam, Germany.
}

proteins through which dopamine acts. One problem to date, has been a lack of information about pharmacological tools that selectively alter neurotransmission in dopaminergic pathways in the insect brain, or that selectively interact with specifi subtypes of insect dopamine receptor.

Insect cellular responses to dopamine, as in vertebrates, are mediated via $G$ protein-coupled receptors (reviewed in Ref. [1]). These receptors are members of a large family of proteins that contain seven transmembrane domains and are coupled to various signal transduction pathways via trimeric G (guanine nucleotide binding) proteins. The dopamine receptors of vertebrates have been categorized into two major subfamilies, D1 receptors and D2 receptors [21]. Activation of members of the D1 receptor family, which includes D1 (D1A) and D5 (D1B) receptors, leads to an increase in intracellular cAMP levels, whereas receptors from the D2 receptor subfamily, which includes 
receptor subtypes D2, D3 and D4, either reduce cAMP levels or act via different second messenger pathways when stimulated. As well as being differentiated on the basis of coupling to the cAMP pathway, vertebrate dopamine receptors can be distinguished on the basis of their ligand binding profile (reviewed in Refs. [30,40,48]). For example, the benzazepine, $R(+)-\mathrm{SCH} 23390$, binds with much higher affinit to vertebrate D1 receptors than to D2 receptors, whereas benzamides, such as sulpiride and eticlopride, and the butyrophenone, spiperone, show higher affinit binding to vertebrate D2 receptors than to members of the vertebrate D1 receptor subfamily. The D1 and D2 receptor subfamilies can also be differentiated using agonists such as SKF 38393, a benzazepine that activates vertebrate D1 receptors at significantl lower concentrations than D2 receptors.

Studies characterizing dopamine receptors in brain tissue from a variety of insects, including cockroach [34,35], locust [9], sphinx moth [14] and honey bee [2,4,23], suggest that insect dopamine receptors are pharmacologically distinct from those found in vertebrates. This suggestion was supported by the cloning and in vitro characterization of two dopamine receptors from Drosophila, DAMB/DopR99B [12,15] and Dmdop1/dDA1 [13,45]. Both of these receptors are positively coupled to adenylyl cyclase, but neither exhibits a pharmacological profil typical of a vertebrate D1 receptor. For example, the vertebrate D1 receptor antagonist, $\mathrm{SCH} 23390$, does not exhibit high affinit binding, nor is it particularly effective at blocking cAMP stimulation via these Drosophila dopamine receptors $[13,45]$. Moreover, the agonist activity of SKF 38393 at these receptors is low compared to vertebrate dopamine receptors $[37,45]$.

The orthologs of Dmdop1/dDA1 and DAMB/DopR99B have been cloned from the honey bee, Apis mellifera. Amdop 1, the ortholog of Dmdop1/dDA1, encodes a dopamine receptor (AmDOP1) that is not only positively coupled to adenylyl cyclase [3] (accession no. Y13429), but also, like the $D m D O P 1 / d \mathrm{DA} 1$ receptor, exhibits a pharmacological profil that is distinct from that of vertebrate D1 receptors [3]. Most strikingly, the vertebrate D2 receptor antagonist spiperone was found to have a higher affinit for AmDOP1 than SCH 23390. A second honey bee dopamine receptor gene, Amdop2, the ortholog of DAMB/DopR99B [11,17] (previously known as Ambar6 or Apis mellifera biogenic amine receptor 6; accession no. AF498306), encodes a protein which is also positively coupled to adenylyl cyclase, but as yet, little is known about the pharmacology of this receptor. In situ analysis of Amdop 1 [3] and Amdop2 [17] transcripts revealed that these two receptors have distinct, but overlapping, patterns of expression in the brain.

$A m D O P 1$ and $A m \mathrm{DOP} 2$ receptors are both like the vertebrate $\mathrm{D} 1$ receptor class in that their activation leads to increased levels of intracellular cAMP, but the amino acid sequences of these two honey bee dopamine receptors are much more divergent than the mammalian D1 receptors, D1/D1A and D5/D1B. The human D1/D1A and D5/D1B receptors have an amino acid sequence identity of $\sim 80 \%$ across their transmembrane domains, whereas AmDOP1 and $A m D O P 2$ contain only about $50 \%$ identity in these regions. Phylogenetic analysis reveals that $A m D O P 1$ is more closely related to the vertebrate D1 receptors than $A m D O P 2$, which groups instead with the vertebrate $\alpha_{1}$ adrenergic receptors [17,22]. While the human D1/D1A and $\mathrm{D} 5 / \mathrm{D} 1 \mathrm{~B}$ receptors share a high level of homology, functional differences between these two receptors have been identified In vitro studies have revealed that expression of the human D5/D1B receptor results in an agonistindependent increase in intracellular cAMP, whereas similar expression levels of the human D1/D1A receptor do not elevate cAMP levels [47]. Agonist-independent (constitutive) activity has also been shown for dopamine receptors cloned from other vertebrates, and this property is now considered a distinguishing characteristic of the vertebrate D5/D1B receptor subclass [33].

Using the baculovirus Autographa californica nucleopolyhedrovirus as an expression vector, we have expressed AmDOP1 and AmDOP2 in insect (Spodoptera frugiperda) cells in order to examine in parallel the pharmacological properties and functional characteristics of these two honey bee dopamine receptors. Measurements of cAMP production are used as a functional assay to examine the agonist and antagonist activities of selected dopamine receptor ligands. The results reveal that these two receptors have similar, but distinct, pharmacological profiles and that $A m \mathrm{DOP} 1$, like the D5/D1B class of vertebrate dopamine receptors, exhibits agonist-independent activity.

\section{Materials and methods}

\section{Construction of baculovirus recombinants}

A baculovirus encoding Amdop1 under the control of the polyhedrin promoter was constructed as follows. An $\sim 1750$ bp fragment containing the coding region of the Amdop 1 gene was isolated from the pBluescript II vector [3] using a PstI site in the vector just upstream of the translation start site and a XhoI site 520 bp downstream of the stop codon. This fragment was then ligated into the donor vector pFastBac (Invitrogen, Bac-To-Bac Baculovirus expression system) that had also been digested with PstI and XhoI. A segment of the pFastBac construct containing the Amdop 1 coding region under the control of the polyhedrin promoter was then recombined from the donor plasmid into the baculovirus genome bacmid (bMON14272) using the Tn7 transposase in E. coli (strain DH10Bac). The bacmid containing the Amdop 1 coding region was then purifie and transfected into Sf21 cells using CellFectin reagent (Invitrogen). A baculovirus re- 
combinant expressing the Amdop2 gene was constructed as described in Humphries et al. [17]. Briefly a $B g l$ II site $30 \mathrm{bp}$ upstream of the translational start site and an XbaI site $65 \mathrm{bp}$ downstream of the stop codon were used to subclone the Amdop 2 coding region into pFastBac. The region containing Amdop 2 and the polyhedrin promoter was then recombined into the bacmid and transfected into Sf21 cells as described above. A control virus not expressing either receptor was made by transfecting the unaltered bMON14272 baculovirus genome bacmid into Sf21 cells. Stocks of virus were produced using protocols described in the Bac-To-Bac manual.

\section{Expression of $A m D O P 1$ and $A m D O P 2$ receptors in Sf21 and Sf9 cells}

Exponentially growing insect cells (either Sf21 or Sf9 cells) were diluted into serum-free medium (Sf-900 II SFM, Invitrogen). Cells $\left(1.8 \times 10^{5} /\right.$ well $)$ were aliquoted into 24-well culture dishes and allowed to adhere overnight at $28{ }^{\circ} \mathrm{C}$ before being infected with virus at a multiplicity of infection of five All cells were then incubated at $28{ }^{\circ} \mathrm{C}$ for $28 \mathrm{~h}$ before being used for intracellular cAMP assays or Northern analysis.

\section{Northern analysis}

Total RNA was isolated from Sf21 cells infected by virus expressing either Amdop1 or Amdop2. Total RNA isolated from cells infected with control virus (see above) was also examined. TRIzol LS reagent (Invitrogen) was used for RNA extraction as described by the manufacturer. Northern analysis was carried out as described by Sambrook et al. [38], with minor modifications RNA (5 $\mu \mathrm{g})$ was loaded onto a $1 \%$ agarose MOPS-formaldehyde gel and fractionated by electrophoresis. RNA molecular weight marker II (Roche) was used as a size standard. For assessment of RNA loading, the gel was stained with 5 $\mu \mathrm{g} / \mathrm{ml}$ ethidium bromide in $1 \times$ MOPS buffer, destained in several changes of distilled water, and photographed. RNA was transferred onto positively charged nylon membranes (Roche) overnight by capillary action using $20 \times$ SSC as transfer buffer, and then fixe on to the membrane by baking at $120{ }^{\circ} \mathrm{C}$ for $30 \mathrm{~min}$. Probes for Amdop 1 and Amdop 2 were labeled with ${ }^{32} \mathrm{P}$ using random primer DNA labeling (GibcoBRL) with fragments containing the entire coding regions of Amdop1 and Amdop2 as templates. Labeled probes were purifie on Sephadex NICK columns (Pharmacia). The membranes were prehybridized in $50 \%$ formamide, $5 \times \mathrm{SSC}, 5 \times$ Denhardt's, $0.1 \mathrm{mg} / \mathrm{ml}$ denatured salmon sperm DNA, and $0.1 \%$ SDS at $42{ }^{\circ} \mathrm{C}$ for $2 \mathrm{~h}$. Amdop 1 or Amdop 2 (50,000 counts/ml) probe was then added, and allowed to hybridize $16 \mathrm{~h}$ at $42{ }^{\circ} \mathrm{C}$. Blots were washed in $1 \times \mathrm{SSC}, 0.1 \% \mathrm{SDS}$ for $5 \mathrm{~min}$ at room temperature and then twice at $60{ }^{\circ} \mathrm{C}$ for $30 \mathrm{~min}$. The membrane was then exposed to X-ray fil for $12-72 \mathrm{~h}$ at
$-80{ }^{\circ} \mathrm{C}$. Quantitation of Northern blots and ethidium bromide stained gels was done using NIH Image.

\section{Analysis of cAMP levels}

Measurements of intracellular cAMP levels were used to monitor the effects of amines, and selected amine-receptor agonists and antagonists, on cells expressing either $A m D O P 1$ or $A m D O P 2$ receptors. Uninfected cells were included as a control. After incubating cells for $28 \mathrm{~h}$ in serum-free medium, this medium was removed and replaced with fresh medium containing $10^{-4} \mathrm{M}$ of the cAMP phosphodiesterase inhibitor 3-isobutyl-1-methylxanthine (IBMX) and the selected $\operatorname{drug}(\mathrm{s})$ at concentrations indicated in the figur legends. Cells were exposed to the $\operatorname{drug}(\mathrm{s})$ for $20 \mathrm{~min}$ at $28{ }^{\circ} \mathrm{C}$. The medium bathing the cells was then removed, the cells were lysed with lysis buffer 1B (supplied in the cAMP assay kit) and the amount of intracellular cAMP was determined using a cAMP enzyme immunoassay (Amersham Pharmacia Biotech). Each sample was analyzed in duplicate. A minimum of three independent assays was carried out for each compound.

\section{Pharmacology of the AmDOP2 receptor}

A pharmacological profil for $A m \mathrm{DOP} 1$ has been presented elsewhere [3]. Prior to comparing responses mediated via $A m \mathrm{DOP} 1$ and $A m \mathrm{DOP} 2$ receptors, the pharmacology of the AmDOP2 receptor was examined. The effects of the biogenic amines dopamine, norepinephrine, octopamine, tyramine, serotonin, and histamine on intracellular cAMP levels were investigated in Sf21 cells expressing the AmDOP2 receptor. Uninfected cells also were examined. For each experiment undertaken in this component of the study, measurement of the level of cAMP in the absence of ligand established the baseline of $100 \%$, and all other measurements are expressed as a percentage of that baseline.

To examine further the pharmacological profil of $A m D O P 2$, the activity of the following vertebrate dopamine receptor agonists was tested on cells expressing the AmDOP2 receptor: SKF 38393, 2-amino-6,7-dihydroxy1,2,3,4-tetra-hydronaphthalene (6,7-ADTN), apomorphine, lisuride, and 6-chloro-7,8-dihydroxy-3-allyl-1-phenyl2,3,4,5-tetrahydro-1H-3-benzazepine (6-chloro-APB). Each ligand was added at a concentration of $10^{-5} \mathrm{M}$ to serum-free medium containing $10^{-4} \mathrm{M}$ IBMX. After exposing cells to ligand for $20 \mathrm{~min}$, cAMP levels were measured as described above. For purposes of comparison, data are expressed as a percentage of the level of cAMP measured in the presence of $10^{-5} \mathrm{M}$ dopamine.

Antagonists were examined for their ability to block dopamine-mediated activation of the AmDOP2 receptor. The antagonist SCH 23390 was chosen because of its known selectivity at vertebrate D1 receptors, while spiperone, eticlopride, and domperidone are selective for 
vertebrate D2 receptors. To enable comparisons to be made with data from previous studies of insect dopamine receptors, chlorpromazine, fluphenazine haloperidol, metoclopramide, $\operatorname{cis}(Z)$-flupentixol and butaclamol were also tested. In addition, the vertebrate D2 receptor agonist, lisuride, was examined for antagonistic activity after it was discovered that it did not act as an agonist at the AmDOP2 receptor. The selected antagonist $\left(10^{-5} \mathrm{M}\right)$ was combined with $10^{-5} \mathrm{M}$ dopamine immediately before both were applied to cells as described above. Levels of cAMP recorded after the application of dopamine plus antagonist are expressed as a percentage of the level of cAMP recorded in cells exposed to $10^{-5} \mathrm{M}$ dopamine alone.

\section{Comparison of AmDOP1 and AmDOP2 pharmacology}

To compare the pharmacology of the two honey bee dopamine receptors, the $A m \mathrm{DOP} 2$ receptor was re-examined in assays in which cells expressing the AmDOP1 receptor were also tested. Responses to the endogenous ligand dopamine, and to the agonist 6,7-ADTN, were examined in the two groups of cells. Agonists were applied to the cells for $20 \mathrm{~min}$, as described above. In a second set of experiments, four antagonists were examined for their ability to block dopamine-mediated cAMP production via the two receptors. As preliminary experiments revealed that dopamine was more potent at activating $A m D O P 1$ receptors than $A m D O P 2$ receptors (see Results), $10^{-6} \mathrm{M}$ dopamine was used to analyze the actions of dopaminereceptor antagonists at $A m D O P 1$ receptors, rather than $10^{-5} \mathrm{M}$ dopamine, the concentration used to examine the effectiveness of antagonists acting via AmDOP2 receptors. After exposing cells to dopamine plus the selected antagonist, cAMP levels were analysed as described above. The number of independent assays carried out for each compound is indicated in the figur legends.

\section{Drugs}

Dopamine hydrochloride; (-)-norepinephrine bitartrate; tyramine hydrochloride; DL-octopamine hydrochloride; 5hydroxytryptamine creatinine sulfate; histamine dihydrochloride; 3-isobutyl-1-methylxanthine (IBMX); haloperidol, spiperone, chlorpromazine hydrochloride, and (-)-sulpiride were purchased from Sigma. $R(+)-\mathrm{SCH} 23390$ hydrochloride, metoclopramide hydrochloride, fluphenazin dihydrochloride, domperidone, $\operatorname{cis}(Z)$-flupen tixol dihydrochloride, $R(+)$-SKF 38393 hydrochloride, $S(-)$-eticlopride hydrochloride, $R(+)$-lisuride hydrogen maleate, $(+)$-butaclamol hydrochloride, (-)-apomorphine hydrochloride, (士)-6-chloro-7,8-dihydroxy-3-allyl-1phenyl-2,3,4,5-tetrahydro-1H-3-benzazepine hydrogen bromide (6-chloro-APB), and ( \pm )-2-amino-6,7-dihydroxy1,2,3,4-tetra-hydronaphthalene hydrobromide (6,7-ADTN) were obtained from Research Biochemicals International.

\section{Data analysis}

Data were analyzed and displayed using Prism 3.0a for Macintosh (GraphPad Software, San Diego, CA, USA, www.graphpad.com). Curve fittin was done using leastsquares analysis. Statistical significanc was determined using one-way analysis of variance (ANOVA) with $P$ values $<0.05$ considered significant Where appropriate, Tukey-Kramer multiple comparison tests were used for post hoc analysis of differences between groups.

\section{Results}

31. Analysis of the activity of biogenic amines at the AmDOP2 receptor

Fig. 1 shows the responses to a range of biogenic amines

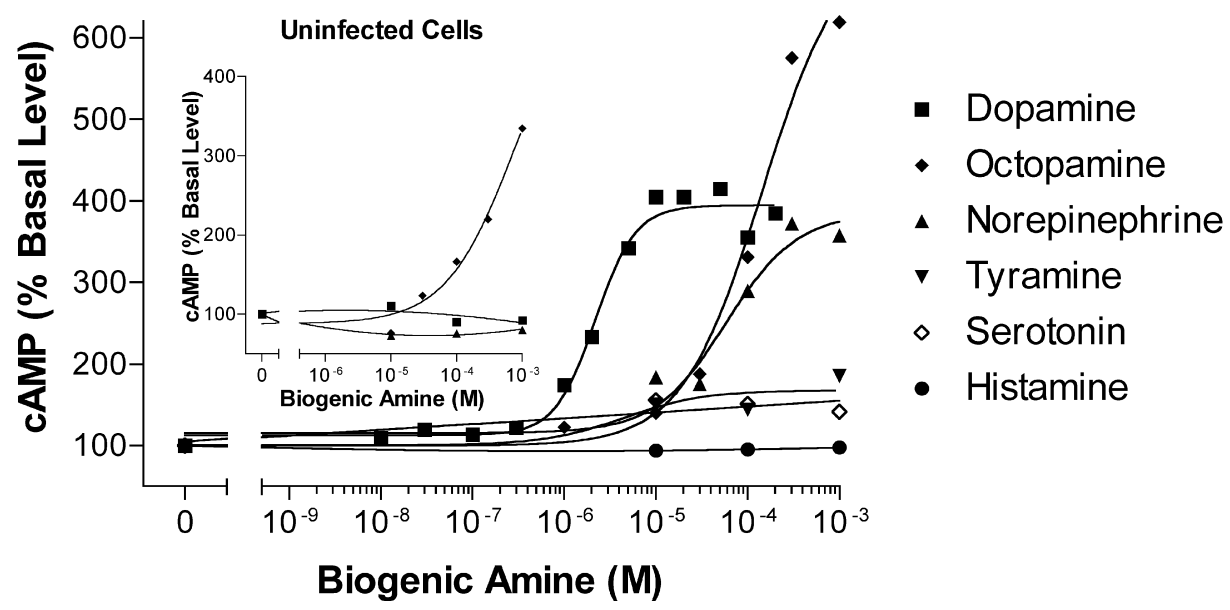

Fig. 1. Biogenic amine-mediated changes in intracellular cAMP level. Responses were examined in Sf21 cells expressing the AmDOP2 receptor, as well as in control (uninfected) cells (inset). All measurements are expressed relative to basal (cAMP detected in the absence of ligand), which provides the baseline of $100 \%$. Curves shown are typical results, and are representative of three to six independent experiments done in duplicate. 
of Sf21 cells expressing the AmDOP2 receptor. Of the biogenic amines tested, dopamine was the most potent (Fig. 1, $\mathrm{EC}_{50} 2.2 \mu \mathrm{M}$ ), and increased cAMP levels approximately fourfold above basal levels. Stimulation of the $A m \mathrm{DOP} 2$ receptor with norepinephrine also increased cAMP levels approximately fourfold above the basal level, but the $\mathrm{EC}_{50}$ for this amine was more than 20-fold higher than that observed for dopamine (Fig. 1, $\mathrm{EC}_{50} 58 \mu \mathrm{M}$ ). Treatment with high concentrations $\left(>10^{-5} \mathrm{M}\right)$ of octopamine also elicited a response. However, even at the highest concentration tested, $10^{-3} \mathrm{M}$, the octopamine response did not reach a plateau which prevented us from determining an $\mathrm{EC}_{50}$ value for this amine. Small increases in cAMP levels could be induced also by treatment of cells with high concentrations of tyramine and serotonin, whereas histamine had no observable effect on cAMP levels. To examine the possibility that dopamine, octopamine or norepinephrine may be acting via a receptor, or receptors, endogenous to Sf21 cells (see Ref. [36]), uninfected (control) cells were treated with these amines (Fig. 1, inset). Analysis of uninfected cells suggested that responses to octopamine (Fig. 1) are mediated, at least in part, by an endogenous octopamine receptor, as high concentrations of octopamine $\left(>10^{-5} \mathrm{M}\right)$ increased cAMP levels in these cells (Fig. 1 inset). However, neither dopamine nor norepinephrine, even at very high concentrations, altered cAMP levels in uninfected cells, indicating that the effects of these amines on cAMP levels in cells expressing the Amdop 2 gene are mediated via AmDOP2 receptors.

\section{Identificatio of synthetic agonists and antagonists of the AmDOP2 receptor}

At a concentration of $10^{-5} \mathrm{M}$, the vertebrate dopamine receptor agonists, 6,7-ADTN, 6-chloro-APB and apomorphine stimulated cAMP production to a level similar to that produced by $10^{-5} \mathrm{M}$ dopamine (Fig. 2A). However, treatment with lisuride, a potent $\mathrm{D} 2$ receptor agonist, or the vertebrate D1 receptor agonist SKF 38393, did not increase cAMP significantl above basal levels; indeed, lisuride was found to act as an antagonist rather than an agonist at the AmDOP2 receptor (see Fig. 2B).

Among the antagonists tested, chlorpromazine, cis(Z)flupentixol fluphenazine butaclamol, SCH 23390, haloperidol, and spiperone, all reduced dopamine-mediated stimulation of cAMP to a level not significantl different from basal levels recorded in the absence of dopamine (Fig. 2B). Significantl less effective at blocking dopamine activation of the AmDOP2 receptor were the antagonists metoclopramide, sulpiride, and eticlopride. Together with published data on the pharmacology of the AmDOP1 receptor [3], these 'point' assays examining the pharmacology of $A m \mathrm{DOP} 2$ enabled us to decide which ligands to use to compare directly the pharmacology of these two honey bee dopamine receptors.
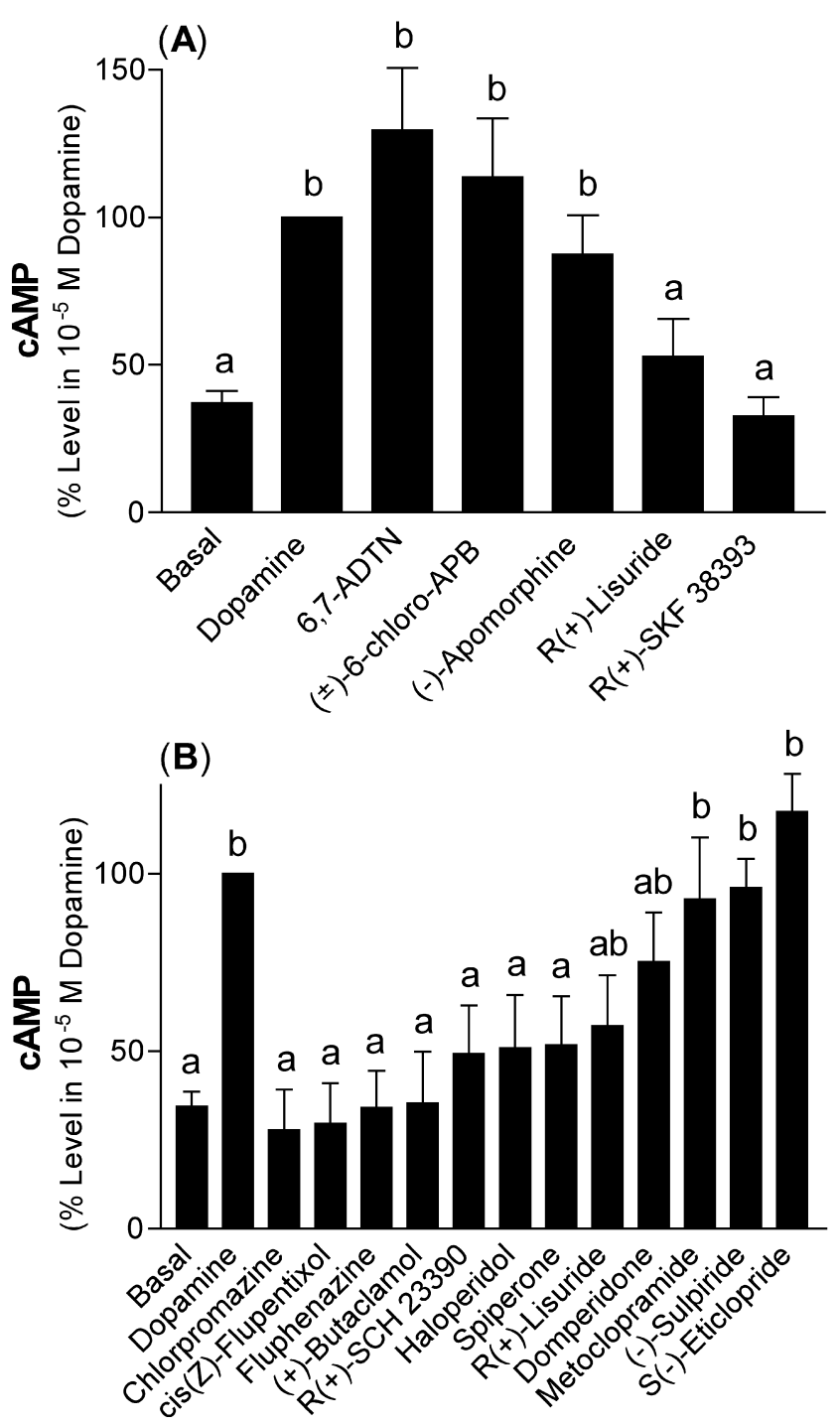

Fig. 2. Responses of $\mathrm{Sf} 21$ cells expressing the $A m \mathrm{DOP} 2$ receptor to (A) selected dopamine receptor agonists at a concentration of $10^{-5} \mathrm{M}$, and (B) dopamine $\left(10^{-5} \mathrm{M}\right)$ plus $10^{-5} \mathrm{M}$ of one of a selection of amine receptor antagonists. Values are expressed as a percentage of the cAMP level in $10^{-5} \mathrm{M}$ dopamine, and are the means \pm S.E.M. of three or four independent experiments. Basal levels of cAMP (Basal) were recorded in the presence of IBMX alone. Overall statistical significanc was determined by one-way ANOVA followed by Tukey-Kramer tests. For the agonists (A), $F=15.15$ and $P<0.0001$. For the antagonists (B), $F=8.99$ and $P<0.0001$. Letters over each bar on the graph indicate whether or not differences between groups are significant Groups that share a letter are not significantl different $(P>0.05)$.

\section{Comparison of AmDOP1 and AmDOP2 receptor pharmacology}

The AmDOP1 and AmDOP2 receptors were assessed under identical conditions to allow direct comparison of pharmacological responses. Northern analysis was used to examine the specificit of expression of the two dopamine receptor genes (Fig. 3). RNA isolated from cells expressing $A m \mathrm{DOP} 1$ receptors, and cells expressing AmDOP2 receptors, was hybridized with probe for Amdop1 (Fig. 


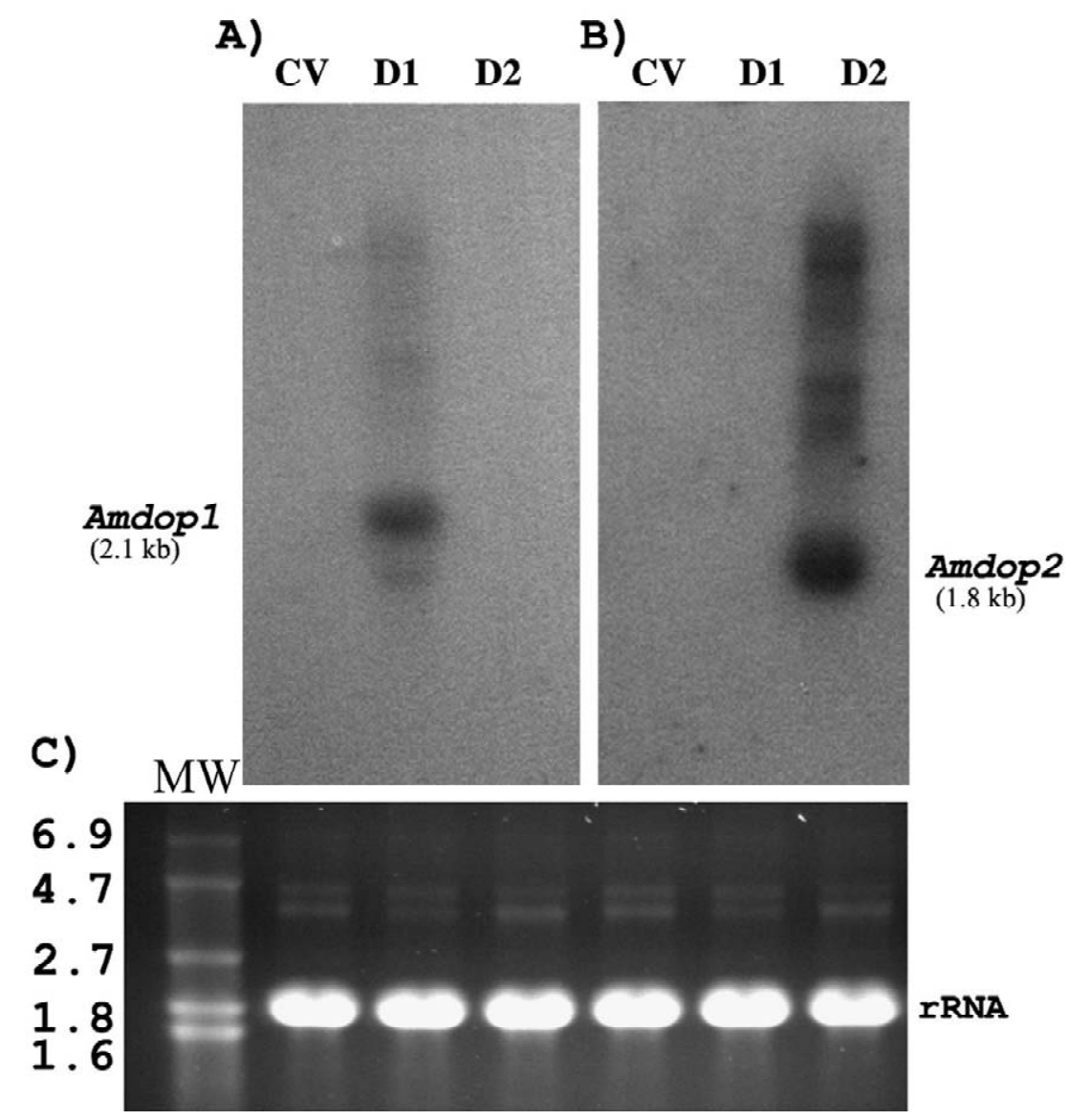

Fig. 3. Northern analysis of Amdop 2 and Amdop 1 expression levels. Total RNA was isolated from Sf21 cells infected with baculovirus expressing Amdop2 (D2), Amdop1 (D1), or no receptor (control virus, CV). (A) Membrane probed with Amdop1 shows a specifi band at $2.1 \mathrm{~kb}$, the expected size for the Amdop 1 transcript produced by the baculovirus construct. (B) Membrane incubated with Amdop 2 probe reveals a band at $1.8 \mathrm{~kb}$, the expected size for the Amdop 2 transcript produced by the recombinant baculovirus. (C) Ethidium bromide staining of the gel before transfer shows equivalent loading of total cellular RNA. The sizes of the molecular weight markers are indicated in kilobases. The most intense band (rRNA) contains the 18S rRNA and the 28S rRNA that dissociates into two equally sized subunits due to the 'hidden break' in insect 28S rRNA [18].

3A), and for Amdop2 (Fig. 3B). RNA isolated from cells infected with control virus (see Methods) was included as a control. The loading of RNA on the gel is shown with ethidium bromide staining in Fig. 3C. The 28S rRNA of many insect species dissociates into two equally sized subunits under denaturing conditions [18], and these subunits are not resolved from the 18S rRNA. After Northern hybridization, specifi bands corresponding to the expected construct sizes were observed. Quantitation of the Amdop 1 and Amdop2 signals with respect to the rRNA band, revealed that Amdop 1 was expressed at about 63\% of the level of Amdop 2 expression. A number of higher molecular weight bands were also recognized by the Amdop 1 and Amdop 2 probes, and these minor bands may be due to the production of 'run on' transcripts from the baculovirus constructs.

Elevated levels of cAMP were observed in cells infected by virus expressing AmDOP1. In 13 independent assays in which Sf21 cells expressing AmDOP1 receptors, cells expressing AmDOP2 receptors, and control (uninfected) cells were examined in parallel, cAMP levels were, on average, more than fourfold higher (4.6 \pm 0.8 S.E.M.) in cells expressing $A m D O P 1$ than in uninfected cells (Fig. 4A). In contrast, the ratio of basal cAMP levels in cells expressing AmDOP2 versus uninfected cells, was close to 1 (1.3 \pm 0.1 S.E.M.). Although variation in the extent of elevation of cAMP levels in Sf21 cells expressing $A m \mathrm{DOP} 1$ was observed, in a majority (85\%) of assays, cells expressing AmDOP1 receptors exhibited basal levels of cAMP that were 1.5-fold or higher than those determined in either cells expressing the AmDOP2 receptor, or uninfected cells (Fig. 4A). A similar trend was apparent in Sf9 cells (Fig. 4B). In this cell line, however, enhancement of basal levels of cAMP in cells expressing the $A m D O P 1$ receptor was less pronounced. On average, basal cAMP levels were $1.7 \pm 0.3$ (S.E.M.)-fold higher in Sf9 cells expressing AmDOP1 receptors than in uninfected cells, while basal cAMP levels in cells expressing $A m D O P 2$ receptors were slightly lower than in uninfected cells $(0.81 \pm 0.08)$.

In Sf21 cells expressing AmDOP1 receptors, basal levels of cAMP were reduced by flupentixo to levels not 


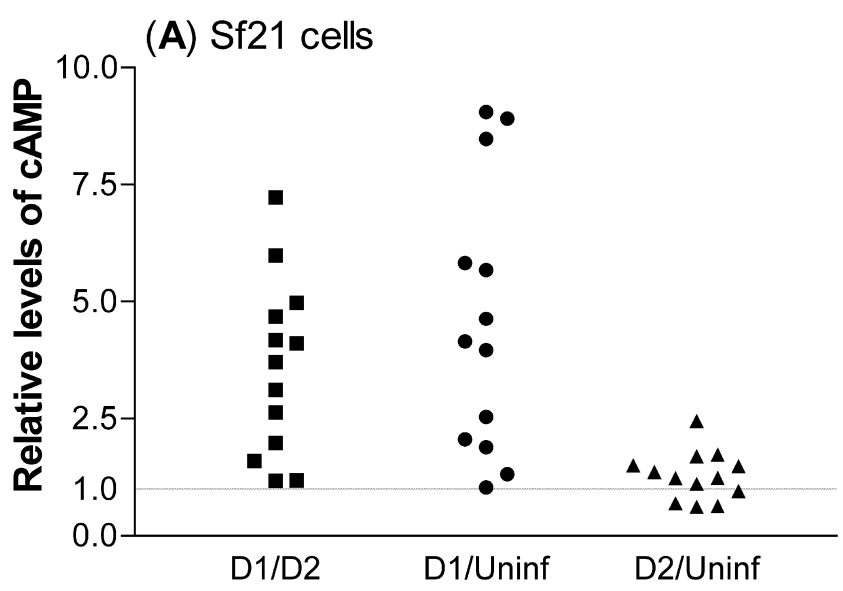

(B) Sf9 cells

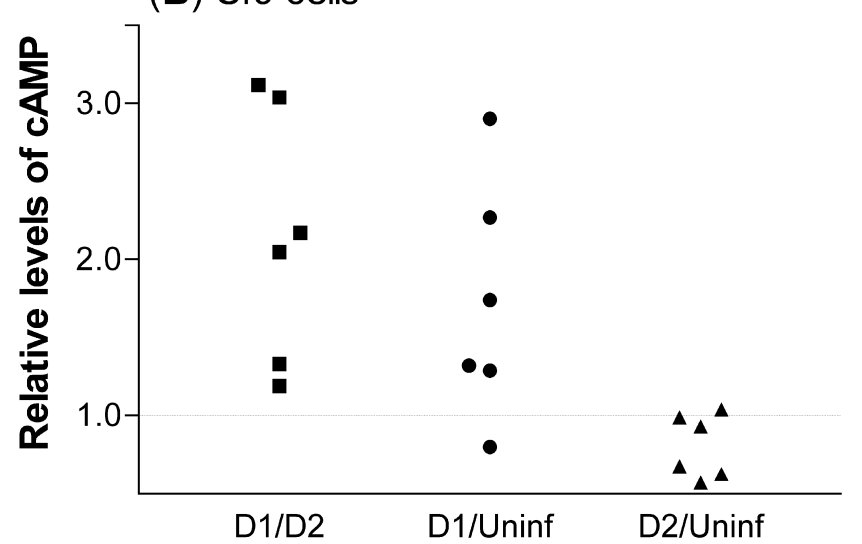

Fig. 4. Relative levels of intracellular cAMP in cells expressing $A m D O P 1$ receptors, $A m D O P 2$ receptors, or neither receptor (uninfected cells). Basal levels of cAMP (measured in $100 \mu \mathrm{M}$ IBMX) determined for cells expressing $A m D O P 1$ receptors (D1), $A m D O P 2$ receptors (D2) and uninfected cells (Uninf) are presented as ratios. (A) Relative basal levels of cAMP were determined for 13 independent assays conducted with Sf21 cells. (B) Relative levels of cAMP for six independent assays using $\mathrm{Sf} 9$ cells. Although the magnitude of the elevation in cAMP varied from assay to assay, the ratio of basal cAMP levels in cells expressing $A m$ DOP1 receptors versus basal levels in uninfected cells (D1/Uninf) is significantl different from the ratio of basal cAMP levels in cells expressing AmDOP2 receptors versus uninfected cells (D2/Uninf) as determined by a paired, two-tailed, $t$-test. (For Sf21 cells: $P=0.0006$, $t=4.6, \mathrm{df}=12$. For Sf9 cells: $P=0.021, t=3.0, \mathrm{df}=5$.)

significantl different from those observed in uninfected cells, and in cells expressing the $A m D O P 2$ receptor (Fig. 5A). Treatment of Sf9 cells expressing AmDOP1 receptors with flupentixo also reduced basal cAMP to a level similar to those observed in cells expressing $A m \mathrm{DOP} 2$, and in uninfected cells (Fig. 5B). Sf21 cells expressing AmDOP1 receptors were treated with a range of flupentixo concentrations revealing that flupentixo reduces basal cAMP levels in a dose-dependent manner (Fig. 5C). Compounds that reduce increases in unstimulated 'baseline' activity (in this case, basal cAMP levels), have been referred to elsewhere as 'negative antagonists' or 'negative agonists'.
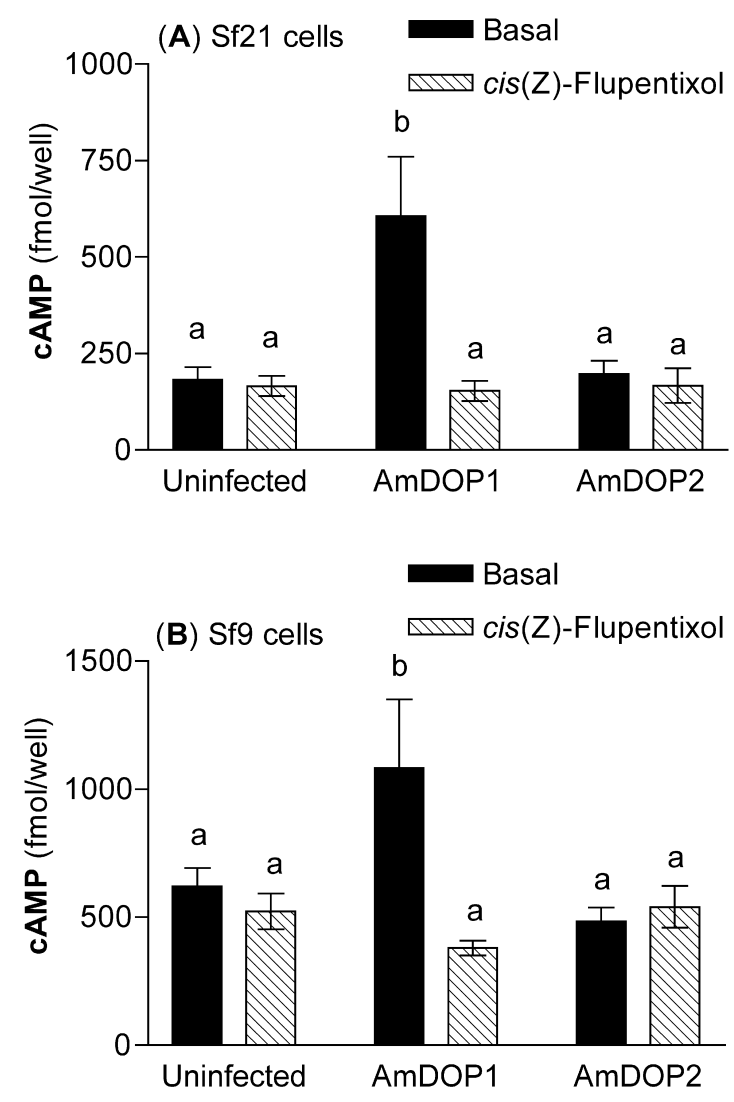

(C) Sf21 cells expressing AmDOP1

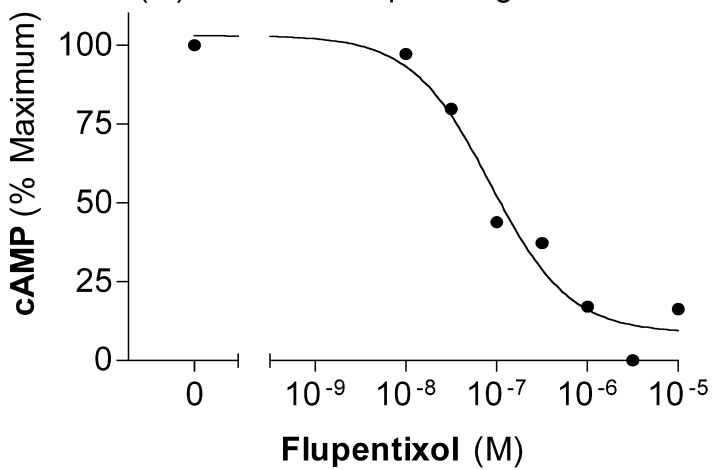

Fig. 5. Effect of flupentixo on basal cAMP levels in cells expressing the $A m \mathrm{DOP} 2$ receptor, the $A m \mathrm{DOP} 1$ receptor, or neither receptor (uninfected cells). (A) Sf21 cells or (B) Sf9 cells were treated with either, IBMX alone (Basal), or with IBMX plus $10^{-5} \mathrm{M} c i s(Z)$-flupentixol Values shown are means \pm S.E.M. for six independent experiments. Overall statistical significanc was determined by one-way ANOVA followed by Tukey-Kramer tests. Letters over each bar on the graph indicate whether or not differences between groups are significant Groups with the same letter are not significantl different. (For Sf21 cells: $F=6.22 ; P=0.0005$; for Sf9 cells: $F=3.88, P=0.0081$.) (C) Treatment of Sf21 cells expressing $A m D O P 1$ receptors with IBMX plus a range of flupentixo concentrations. The point labeled ' 0 ' indicates the cAMP level measured with IBMX alone (the basal level). The curve shown is representative of three independent experiments done in duplicate. 
However, the term that is now most commonly used to describe such compounds is 'inverse agonists' (reviewed in Ref. [5]).

In all three assays in which the effects of dopamine on cells expressing $A m D O P 1$ and $A m D O P 2$ were examined in parallel, dopamine was found to be more potent at stimulating cAMP production via $A m \mathrm{DOP} 1$ receptors than via $A m$ DOP2 receptors (Fig. 6A, see also Table 1). The dopamine receptor agonist 6,7-ADTN was also more potent at $A m D O P 1$ receptors than $A m D O P 2$ (Fig. 6B and Table 1). Direct comparison of the ability of flupentixol butaclamol, spiperone and SCH 23390 to block dopamine-
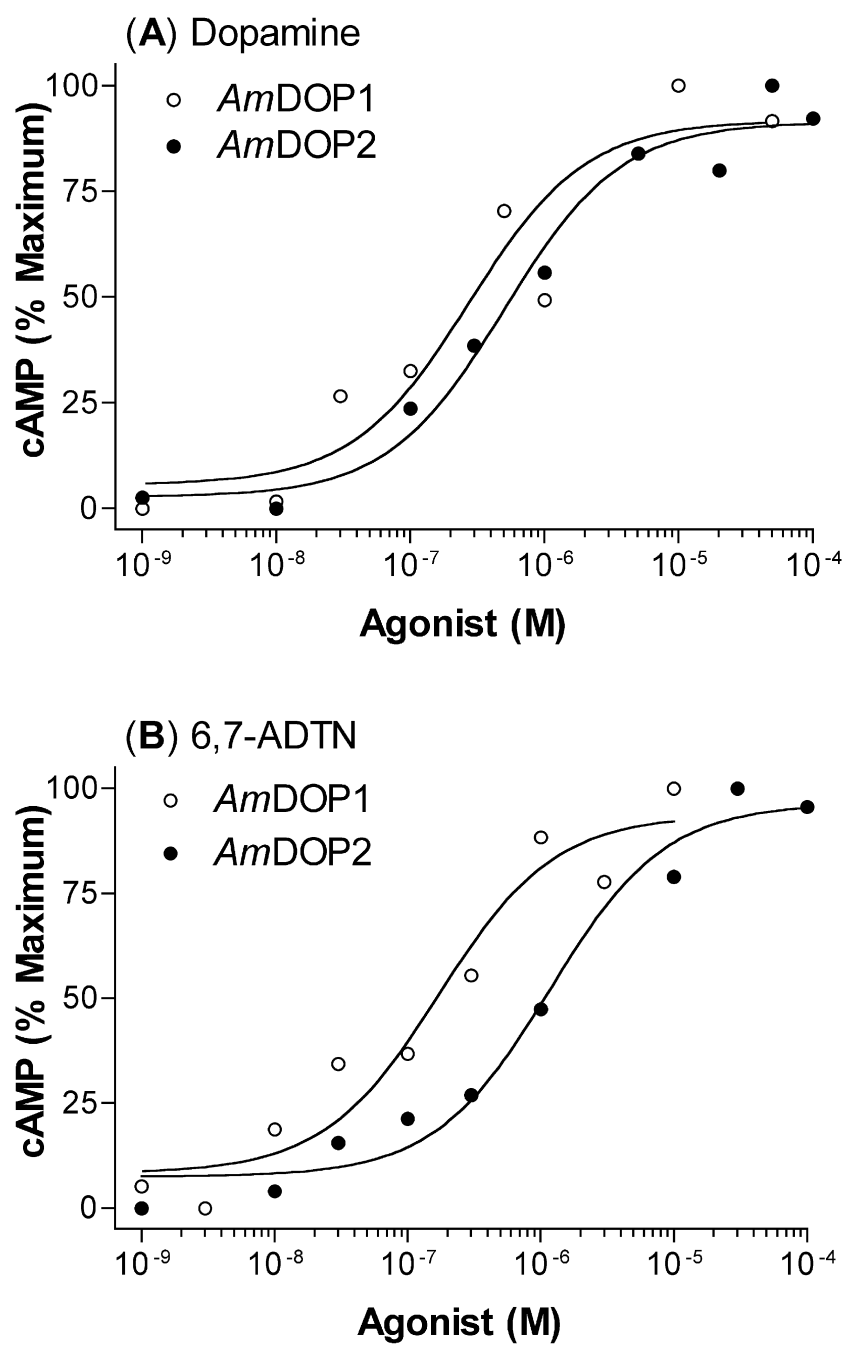

Fig. 6. Agonist response curves for $\mathrm{Sf} 21$ cells expressing either $A m \mathrm{DOP} 1$ or $A m \mathrm{DOP} 2$ receptors. For these experiments, cells expressing $A m \mathrm{DOP} 2$ receptors were examined in parallel with cells expressing AmDOP1 receptors. To allow comparison, the data have been normalized with the minimum cAMP level set to zero and the maximum to $100 \%$ for each curve. Representative curves are shown for three independent experiments done in duplicate. (A) Curves illustrating the change in cAMP levels due to treatment with a range of dopamine concentrations. (B) Representative curves for the response of cells expressing each receptor to 6,7-ADTN at the concentrations indicated. The mean $\mathrm{EC}_{50}$ values from independent experiments are reported in Table 1 .
Thble 1

Comparison of mean $\mathrm{EC}_{50}$ and $\mathrm{IC}_{50}$ values of different compounds for cells expressing AmDOP1 or AmDOP2 receptors

\begin{tabular}{llll}
\hline & Ligand & $A m \mathrm{DOP} 1$ & $A m \mathrm{DOP} 2$ \\
\hline $\mathrm{EC}_{50}$ in $\mu \mathrm{M}$ & Dopamine & 0.36 & 2.2 \\
$\left(\mathrm{pEC}_{50} \pm \mathrm{SEM}, n\right)$ & & $(6.44 \pm 0.08,3)$ & $(5.66 \pm 0.19,6)$ \\
& 6,7 -ADTN & 0.65 & 5.1 \\
& & $(6.19 \pm 0.23,3)$ & $(5.29 \pm 0.44,3)$ \\
& & 0.20 & 0.00380 \\
$\mathrm{IC}_{50}$ in $\mu \mathrm{M}^{\mathrm{a}}$ & cis $(Z)$-Flupentixol & $(6.71 \pm 0.15,3)$ & $(8.42 \pm 0.02,3)$ \\
$\left(\mathrm{pIC}_{50} \pm \mathrm{SEM}, n\right)$ & & 0.54 & 0.081 \\
& $(+)$-Butaclamol & $(6.27 \pm 0.05,3)$ & $(7.09 \pm 0.32,3)$ \\
& & 2.2 & 8.5 \\
& Spiperone & $(5.66 \pm 0.03,3)$ & $(5.07 \pm 0.07,3)$ \\
& & 8.1 & 17 \\
& $R(+)-\mathrm{SCH} 23390$ & $(5.09 \pm 0.09,3)$ & $(4.78 \pm 0.48,3)$ \\
& & &
\end{tabular}

${ }^{\mathrm{a}} \mathrm{IC}_{50}$ values were determined in the presence of $1 \mu \mathrm{M}$ dopamine for assays with $A m \mathrm{DOP} 1$ and $10 \mu \mathrm{M}$ dopamine for assays with $A m \mathrm{DOP} 2$.

mediated stimulation of cAMP in cells expressing $A m \mathrm{DOP} 1$ (Fig. 7A) or $A m \mathrm{DOP} 2$ (Fig. 7B) revealed that at both receptors, flupentixo was the most potent of the antagonists tested, followed by butaclamol, spiperone and then SCH 23390 (Table 1).

\section{Discussion}

Direct comparison of AmDOP1 and AmDOP2 receptors revealed that, in a majority of assays, $\mathrm{Sf} 21$ or $\mathrm{Sf} 9$ cells expressing AmDOP1 contained higher basal levels of cAMP than either cells expressing AmDOP2, or uninfected cells. These results suggest that the AmDOP1 receptor exhibits agonist-independent activation. Interestingly, a recent review of $\mathrm{G}$ protein-coupled receptors (GPCR) reported that more than $40 \%$ of all characterized GPCRs are constitutively active [41]. Although Northern analysis does not provide for the direct determination of receptor levels, analysis of cells expressing Amdop1 or Amdop2 revealed that Amdop 2 was expressed at slightly higher levels than Amdop 1 (Fig. 3). While variations in AmDOP1 receptor density may contribute to the variations in basal levels of cAMP (Fig. 4), it seems unlikely that constitutive activity of $A m D O P 1$ is an artifact arising from the expression of high levels of $A m \mathrm{DOP} 1$ receptors. There are several lines of evidence that support this argument. Firstly, expression of similar high levels (above physiological levels) of $\mathrm{G}$ protein-coupled receptors have demonstrated that, under the same conditions, some receptors have high levels of constitutive activity while others show little or no agonist independent activity [7,42,47] (see Ref. [41] for a review). Secondly, GPCRs that have been shown to be constitutively active in heterologous expression systems have been found to be constitutively active also, when analyzed at physiological levels in their native tissues [16,31]. Thirdly, GPCRs that are not constitutively activated in recombinant expression systems, remain not 

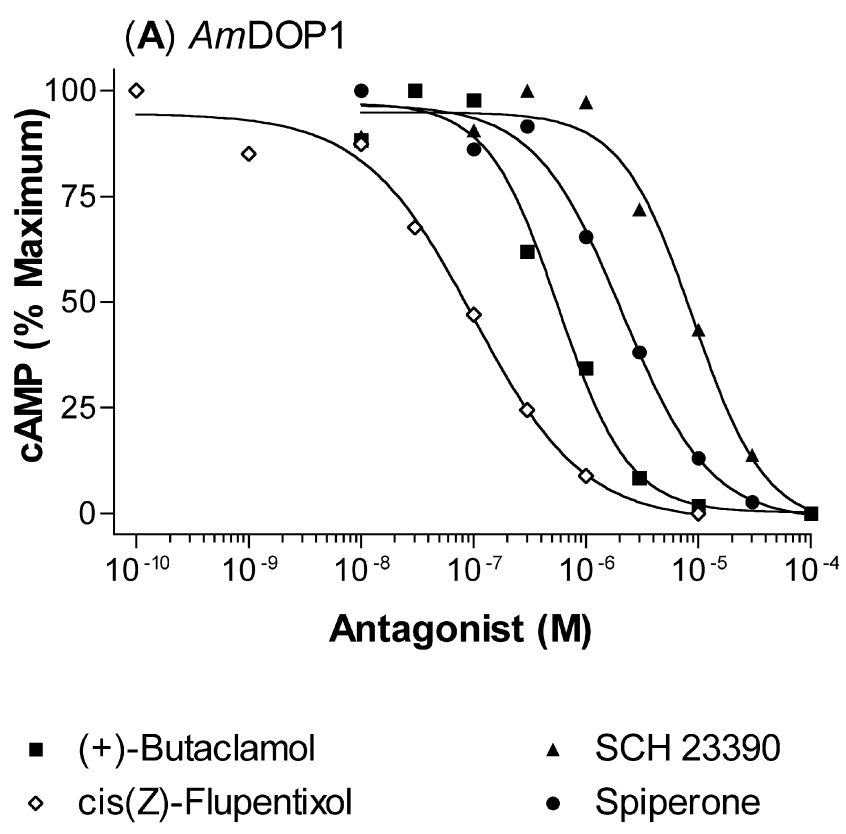

(B) $A m D O P 2$

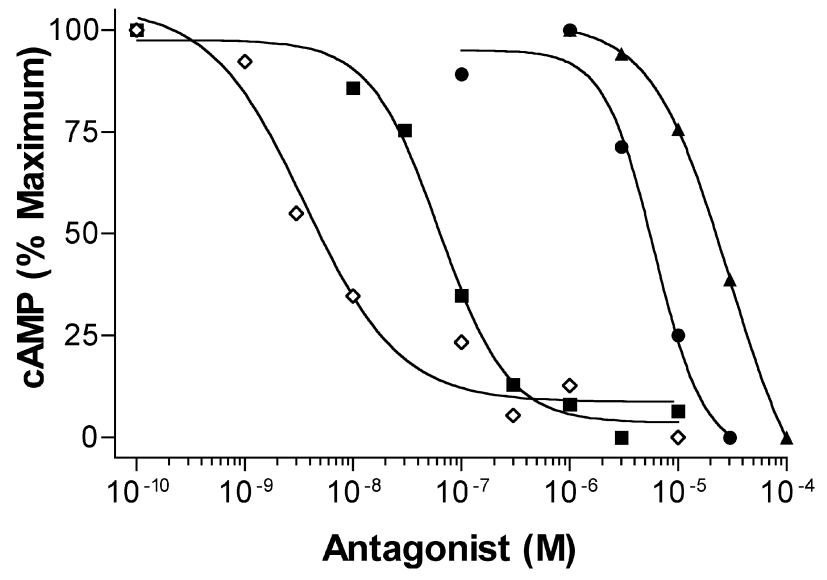

Fig. 7. Effects of dopamine receptor antagonists acting via AmDOP1 receptors (A) or AmDOP2 receptors (B). (A) Cells expressing AmDOP1 receptors were exposed to dopamine $\left(10^{-6} \mathrm{M}\right)$ and the selected antagonist at the range of concentrations indicated. (B) Cells expressing AmDOP2 receptors were treated with $10^{-5} \mathrm{M}$ dopamine and the antagonist indicated. For comparison, the data have been normalized so that for each curve, the maximum cAMP level determined was set at $100 \%$ and the minimum level is zero. Representative curves are shown from three experiments done in duplicate. The mean $\mathrm{IC}_{50}$ values derived from these experiments are shown in Table 1.

constitutively activated in their native systems, even when expressed many times over their physiological levels [50]. Taken together, these data argue that constitutive activity is an intrinsic feature of some receptors, and is not an artifact due to over expression in recombinant systems. In this context, it is significant that despite the fact that Amdop 1 and Amdop 2 were driven off the same, very strong promoter, AmDOP1 receptors exhibited constitutive activity, whereas $A m D O P 2$ receptors did not.
Constitutive activation of adenylyl cyclase by a dopamine receptor is not unique to the $A m \mathrm{DOP} 1$ receptor. Like $A m \mathrm{DOP} 1$, the vertebrate $\mathrm{D} 5 / \mathrm{D} 1 \mathrm{~B}$ receptor is also constitutively activated [47], a property that serves to differentiate between mammalian D1/D1A and D5/D1B receptors. Agonist-independent activities have also been associated with D1-like dopamine receptors in nonmammalian vertebrates, such as eel [7] and frog [44], and recent evidence suggests that a $C$. elegans dopamine receptor may also exhibit this property (Sanyal and Van Tol, personal communication), but the present study is the firs to identify such a property in an insect dopamine receptor.

While the physiological relevance of agonist-independent receptor activity remains unknown, higher levels of intracellular cAMP resulting from expression of a constitutively activated receptor may have a significan impact on the physiological properties of a cell. For example, cAMP activates the cAMP-dependent protein kinase, protein kinase $\mathrm{A}$, which in turn phosphorylates target proteins that can include ion channels, as well as proteins involved in regulation of gene expression. The increase in basal levels of cAMP in cells expressing constitutively activated receptors such as AmDOP1 or D5/D1B, lowers the signalto-noise ratio, an observation that has led to the suggestion that constitutively active receptors may act as on/off switches [24]. The possibility that endogenous ligands may exist that mimic the effects of inverse agonists, such as flupentixo (see Fig. 5), in reducing the agonist-independent activity of constitutively activated receptors is also of great interest, and may be highly significan in terms of the functional properties of such receptors. While endogenous inverse agonists have yet to be identifie for biogenic amine receptors, they have been described for other $G$ protein-coupled receptors. For example, the endogenous agouti and agouti-related proteins act as inverse agonists at melanocortin receptors $[32,43]$.

The structural basis of the constitutive activity of dopamine receptors has been investigated in a number of studies $[8,10,19,20]$. The construction of chimeric receptor proteins, in which the carboxyl-terminal tail sequence of the D5/D1B receptor was exchanged with that of the D1/D1A receptor, has identifie a region of the carboxylterminus located $\sim 70$ residues downstream from the seventh transmembrane region as being important for constitutive activity of the human D5/D1B receptor [10]. Interestingly, the carboxyl tail of the $A m \mathrm{DOP} 1$ receptor is shorter than the human D5/D1B receptor (71 amino acids versus 113) and does not contain the corresponding region. A residue in the third cytoplasmic loop has also been implicated in partially modulating the constitutive activity of D5/D1B [8]. The residue is isoleucine in the D5/D1B receptor, and phenylalanine in the $\mathrm{D} 1 / \mathrm{D} 1 \mathrm{~A}$, and in the AmDOP1 receptor, the corresponding residue is a histidine. Such comparisons suggest that the constitutive activity of AmDOP1 may be conferred via a different structural mechanism than for vertebrate dopamine receptors. 
In addition to the agonist-independent activity of $A m \mathrm{DOP} 1$, a direct comparison of AmDOP1 and AmDOP2 receptors reveals differences between these two honey bee dopamine receptors that parallel differences between vertebrate D1/D1A and D5/D1B receptors. For example, the $A m D O P 1$ receptor reaches maximal activation with about 10-fold lower concentrations of dopamine and 6,7-ADTN than $A m \mathrm{DOP} 2$. In vertebrates also, the constitutively activated D1 receptor, D5/D1B, has a 10-fold higher affinit for dopamine than the D1/D1A receptor. The antagonists flupentixo and butaclamol, on the other hand, have a higher affinit for D1/D1A than D5/D1B receptors. In a striking parallel, these two antagonists appeared also to be more potent at blocking responses mediated via $A m \mathrm{DOP} 2$ receptors than the constitutively activated receptor, AmDOP1. These results suggest that although the $A m \mathrm{DOP} 1$ and $A m \mathrm{DOP} 2$ receptors have a relatively low level of homology compared to the D1/D1A and D5/D1B receptors, there may be functional parallels between these honey bee and mammalian receptors. Evidence suggests that AmDOP1 receptors are expressed widely throughout the brain of the honey bee [3] whereas $A m$ DOP2 receptors are restricted mainly to the mushroom bodies of the protocerebrum [17]. In the mammalian brain, however, the D1/D1A receptor is expressed more widely than the constitutively activated receptor, D5/D1B $[30,48]$.

This study is the firs to provide evidence for a constitutively activated invertebrate dopamine receptor. Although phylogenetic analysis shows that, unlike the vertebrate D1/D1A and D5/D1B receptors, AmDOP1 and AmDOP2 are not closely related paralogs $[17,22]$, it is significan that this property is conserved between insects and mammals. The direct comparison between AmDOP1 and AmDOP2 has shown that although both receptors upregulate intracellular cAMP levels in the presence of dopamine, the two receptors have functional properties that enable them to be clearly differentiated.

\section{Acknowledgements}

We would like to thank Dr. Merideth Humphries (University of California, Davis, CA, USA) for sharing her results with us prior to publication and for many informative discussions during the course of this work. We also owe a debt of gratitude to Dr. Fiona Pringle (University of Otago) for assistance with the insect cell lines, and to Drs. Robert Purves and Brent Sinclair (University of Otago) for helpful discussions on data analysis. This work was supported by The Royal Society of New Zealand Marsden Fund, and by an Alexander von Humboldt-Foundation F. Lynen-Fellowship awarded to W.B. The experiments described in this work comply with the laws of New Zealand regulating scientifi research.

\section{References}

[1] W Blenau, A. Baumann, Molecular and pharmacological properties of insect biogenic amine receptors: lessons from Drosophila melanogaster and Apis mellifera, Arch. Insect Biochem. Physiol. 48 (2001) 13-38.

[2] W Blenau, J. Erber, Behavioural pharmacology of dopamine, serotonin and putative aminergic ligands in the mushroom bodies of the honeybee (Apis mellifera), Behav. Brain Res. 96 (1998) 115124.

[3] W Blenau, J. Erber, A. Baumann, Characterization of a dopamine D1 receptor from Apis mellifera: cloning, functional expression, pharmacology, and mRNA localization in the brain, J. Neurochem. 70 (1998) 15-23.

[4] W Blenau, T. May, J. Erber, Characterization of a dopaminesensitive [H-3]LSD binding site in honeybee (Apis mellifera) brain, Comp. Biochem. Physiol. C 110 (1995) 197-205.

[5] R Bond, G. Milligan, M. Bouvier, Inverse agonism, in: T. Kenakin, J.A. Angus (Eds.), The Pharmacology of Functional, Biochemical and Recombinant Receptor Systems, Vol. 148, Springer-Verlag, Berlin, 2000, pp. 167-182.

[6] J. Bozic, J. Woodring, Variations of brain biogenic amines in mature honeybees and induction of recruitment behavior, Comp. Biochem. Physiol. A Mol. Integr. Physiol. 120 (1998) 737-744.

[7] B Cardinaud, K.S. Sugamori, S. Coudouel, J.D. Vincent, H.B. Niznik, P. Vernier, Early emergence of three dopamine D1 receptor subtypes in vertebrates. Molecular phylogenetic, pharmacological, and functional criteria definin D1A, D1B, and D1C receptors in European eel Anguilla anguilla, J. Biol. Chem. 272 (1997) 27782787.

[8] S Charpentier, K.R. Jarvie, D.M. Severynse, M.G. Caron, M. Tiberi, Silencing of the constitutive activity of the dopamine D1B receptor. Reciprocal mutations between D1 receptor subtypes delineate residues underlying activation properties, J. Biol. Chem. 271 (1996) 28071-28076.

[9] J. Degen, M. Gewecke, T. Roeder, The pharmacology of a dopamine receptor in the locust nervous tissue, Eur. J. Pharmacol. 396 (2000) 59-65.

[10] L. Demchyshyn, F. McConkey, H.B. Niznik, Dopamine D5 receptor agonist high affinit and constitutive activity profil conferred by carboxyl-terminal tail sequence, J. Biol. Chem. 275 (2000) 23446-23455.

[11] P.R. Ebert, J.E. Rowland, D.P. Toma, Isolation of seven unique biogenic amine receptor clones from the honey bee by library scanning, Insect Mol. Biol. 7 (1998) 151-162.

[12] G Feng, F. Hannan, V. Reale, Y.Y. Hon, C.T. Kousky, P.D. Evans, L.M. Hall, Cloning and functional characterization of a novel dopamine receptor from Drosophila melanogaster, J. Neurosci. 16 (1996) 3925-3933.

[13] F Gotzes, S. Balfanz, A. Baumann, Primary structure and functional characterization of a Drosophila dopamine receptor with high homology to human D1/5 receptors, Receptors Channels 2 (1994) 131-141.

[14] NA. Granger, R. Ebersohl, T.C. Sparks, Pharmacological characterization of dopamine receptors in the corpus allatum of Manduca sexta larvae, Insect Biochem. Mol. Biol. 30 (2000) 755-766.

[15] KA. Han, N.S. Millar, M.S. Grotewiel, R.L. Davis, DAMB, a novel dopamine receptor expressed specificall in Drosophila mushroom bodies, Neuron 16 (1996) 1127-1135.

[16] HE. Hopkinson, M.L. Latif, S.J. Hill, Non-competitive antagonism of beta(2)-agonist-mediated cyclic AMP accumulation by ICI 118551 in $\mathrm{BC} 3 \mathrm{H} 1$ cells endogenously expressing constitutively active beta(2)-adrenoceptors, Br. J. Pharmacol. 131 (2000) 124130.

[17] MA. Humphries, J.A. Mustard, S.T. Hunter, A.R. Mercer, V.K. 
Ward, P.R. Ebert, Expression of a dopamine receptor in the honey bee brain is correlated with adult development and behavioural plasticity, J. Neurobiol., in press.

[18] H Ishikawa, R.W. Newburgh, Studies of the thermal conversion of 28 S RNA of Galleria mellonella (L.) to an $18 \mathrm{~S}$ product, J. Mol. Biol. 64 (1972) 135-144.

[19] RM. Iwasiow, M.F. Nantel, M. Tiberi, Delineation of the structural basis for the activation properties of the dopamine D1 receptor subtypes, J. Biol. Chem. 274 (1999) 31882-31890.

[20] A Jackson, R.M. Iwasiow, M. Tiberi, Distinct function of the cytoplasmic tail in human D1-like receptor ligand binding and coupling, FEBS Lett. 470 (2000) 183-188.

[21] J.W. Kebabian, D.B. Calne, Multiple receptors for dopamine, Nature 277 (1979) 93-96.

[22] I.C. Kokay, P.R. Ebert, B.S. Kirchhof, A.R. Mercer, Distribution of dopamine receptors and dopamine receptor homologs in the brain of the honey bee, Apis mellifera L., Microsc. Res. Tech. 44 (1999) 179-189.

[23] I.C. Kokay, A.R. Mercer, Characterisation of dopamine receptors in insect (Apis mellifera) brain, Brain Res. 706 (1996) 47-56.

[24] RJ. Lefkowitz, S. Cotecchia, P. Samama, T. Costa, Constitutive activity of receptors coupled to guanine nucleotide regulatory proteins, Trends Pharmacol. Sci. 14 (1993) 303-307.

[25] CS. Macmillan, A.R. Mercer, An investigation of the role of dopamine in the antennal lobes of the honeybee, Apis mellifera, J. Comp. Physiol. A 160 (1987) 359-366.

[26] R Menzel, A. Heyne, C. Kinzel, B. Gerber, A. Fiala, Pharmacological dissociation between the reinforcing, sensitizing, and response-releasing functions of reward in honeybee classical conditioning, Behav. Neurosci. 113 (1999) 744-754.

[27] R Menzel, B. Michelsen, P. Ruffer, M. Sugawa (Eds.), Neuropharmacology of Learning and Memory in Honey Bees, Springer, Berlin, 1988, pp. 331-350.

[28] AR. Mercer, R. Menzel, The effects of biogenic amines on conditioned and unconditioned responses to olfactory stimuli in the honeybee Apis mellifera, J. Comp. Physiol. A 145 (1982) 363-368.

[29] DB. Michelsen, Catecholamines affect storage and retrieval of conditioned odour stimuli in honey bees, Comp. Biochem. Physiol. 91C (1988) 479-482.

[30] C Missale, S.R. Nash, S.W. Robinson, M. Jaber, M.G. Caron, Dopamine receptors: from structure to function, Physiol. Rev. 78 (1998) 189-225.

[31] S Morisset, A. Rouleau, X. Ligneau, F. Gbahou, J. TardivelLacombe, H. Stark, W. Schunack, C.R. Ganellin, J.C. Schwartz, J.M. Arrang, High constitutive activity of native $\mathrm{H} 3$ receptors regulates histamine neurons in brain, Nature 408 (2000) 860-864.

[32] WA. Nijenhuis, J. Oosterom, R.A. Adan, $\operatorname{AgRP}(83-132)$ acts as an inverse agonist on the human-melanocortin-4 receptor, Mol. Endocrinol. 15 (2001) 164-171.

[33] HB. Niznik, F. Liu, K.S. Sugamori, B. Cardinaud, P. Vernier, Expansion of the dopamine D1 receptor gene family: definin molecular, pharmacological, and functional criteria for D1A, D1B, D1C, and D1D receptors, Adv. Pharmacol. 42 (1998) 404-408.

[34] HJ. Notman, R.G.H. Downer, Binding of $\left[{ }^{3} \mathrm{H}\right]$ pifluthixol a dopamine antagonist, in the brain of the american cockroach, Periplaneta americana, Insect Biochem. 17 (1987) 587-590.
[35] G. Orr, J.W. Gole, H.J. Notman, R.G. Downer, Pharmacological characterisation of the dopamine-sensitive adenylate cyclase in cockroach brain: evidence for a distinct dopamine receptor, Life Sci. 41 (1987) 2705-2715.

[36] N Orr, G.L. Orr, R.M. Hollingworth, The Sf9 cell line as a model for studying insect octopamine-receptors, Insect Biochem. Mol. Biol. 22 (1992) 591-597.

[37] V Reale, F. Hannan, L.M. Hall, P.D. Evans, Agonist-specifi coupling of a cloned Drosophila melanogaster D1-like dopamine receptor to multiple second messenger pathways by synthetic agonists, J. Neurosci. 17 (1997) 6545-6553.

[38] J. Sambrook, E.F. Fritsch, T. Maniatis, Molecular Cloning: A Laboratory Manual, Cold Spring Harbor Press, Cold Spring Harbor, 1989.

[39] DJ. Schulz, G.E. Robinson, Biogenic amines and division of labor in honey bee colonies: behaviorally related changes in the antennal lobes and age-related changes in the mushroom bodies, J. Comp. Physiol. A 184 (1999) 481-488.

[40] P. Seeman, H.H. Van Tol, Dopamine receptor pharmacology, Trends Pharmacol. Sci. 15 (1994) 264-270.

[41] R Seifert, K. Wenzel-Seifert, Constitutive activity of G-proteincoupled receptors: cause of disease and common property of wildtype receptors, Naunyn Schmiedebergs Arch. Pharmacol. 366 (2002) 381-416.

[42] R Seifert, K. Wenzel-Seifert, Unmasking different constitutive activity of four chemoattractant receptors using $\mathrm{Na}^{+}$as universal stabilizer of the inactive (R) state, Receptors Channels 7 (2001) 357-369.

[43] W Siegrist, R. Drozdz, R. Cotti, D.H. Willard, W.O. Wilkison, A.N. Eberle, Interactions of alpha-melanotropin and agouti on B16 melanoma cells: evidence for inverse agonism of agouti, J. Recept. Signal Transduct. Res. 17 (1997) 75-98.

[44] KS. Sugamori, L.L. Demchyshyn, M. Chung, H.B. Niznik, D1A, D1B, and D1C dopamine receptors from Xenopus laevis, Proc. Natl. Acad. Sci. USA 91 (1994) 10536-10540.

[45] KS. Sugamori, L.L. Demchyshyn, F. McConkey, M.A. Forte, H.B. Niznik, A primordial dopamine D1-like adenylyl cyclase-linked receptor from Drosophila melanogaster displaying poor affinit for benzazepines, FEBS Lett. 362 (1995) 131-138.

[46] D. Taylor, G.E. Robinson, B.J. Logan, R. Laverty, A.R. Mercer, Changes in brain amine levels associated with the morphological and behavioural development of the worker honeybee, J. Comp. Physiol. A 170 (1992) 715-721.

[47] M Tiberi, M.G. Caron, High agonist-independent activity is a distinguishing feature of the dopamine D1B receptor subtype, J. Biol. Chem. 269 (1994) 27925-27931.

[48] D Vallone, R. Picetti, E. Borrelli, Structure and function of dopamine receptors, Neurosci. Biobehav. Rev. 24 (2000) 125-132.

[49] C Wagener-Hulme, J.C. Kuehn, D.J. Schulz, G.E. Robinson, Biogenic amines and division of labor in honey bee colonies, J. Comp. Physiol. A 184 (1999) 471-479.

[50] YY. Zhou, D. Yang, W.Z. Zhu, S.J. Zhang, D.J. Wang, D.K. Rohrer, E. Devic, B.K. Kobilka, E.G. Lakatta, H. Cheng, R.P. Xiao, Spontaneous activation of beta(2)- but not beta(1)-adrenoceptors expressed in cardiac myocytes from beta(1)beta(2) double knockout mice, Mol. Pharmacol. 58 (2000) 887-894. 